\title{
Work Organisation Supported by an Expert System in Agriculture
}

\author{
Janos Felfoldi \\ University of Debrecen, Centre of Agricultural Sciences, \\ Institute of Agricultural Economics and Rural Development, \\ Department of Labour Science, Debrecen
}

SUMMARY

Expert systems are softwares that incorporate the experience of an expert and support decision makers by leading them through the thinking processes of an expert in the form of „if...then” rules. To use an expert system we have to work with knowledge expressed in a pre-determined form. To do so, we used a shell that can be purchased, and we acquired knowledge about the topic from experts through interviews and personal monitoring. Attributes that are non-measurable, such as many of the factors determining work-place organisation and revealing knowledge related to it, can be formed into words by using expert systems. The goal of the study was to present a suggested form of expert system model to help judge the level of work-place organisation.

\section{INTRODUCTION}

Managerial decision making on organisation can be made easier and more efficient using suitable information and decision support. Expert systems are softwares that incorporate the experience of an expert and support decision makers by leading them through the thinking processes of an expert in the form of „if...then” rules.

Baracskai (1997) suggests that we should use expert systems because any other decision support system is inferior. It is not mechanical problem solving that these systems, based on knowledge, do: they „work like experts can be expected to”.

It causes a lot of misunderstanding that users expect these systems to completely solve a problem. Many expert systems failed to be used in practice because of the poor introduction to the organisation (Cooke, 1991).

Innovation, willingness to apply and consequent implementation are the criteria of the successful application of a system (Badiru, 1988; Benders and Menders, 1993; Dologite and Mockler, 1989). Furthermore, poor introduction to the market and integration are hindrances to expansive application. Wiig (1990) gives a list of business reasons for using expert systems. It supports the justification of an expert system that an expert gains knowledge over time (5-10 years) to be able to find solutions to problems under conditions with lack of information. A developed and introduced expert system can be copied and used immediately (Szenteleki et al., 1998). Kunnathur et al. (1996) examined successful users and stated that all the companies considered it useful to preserve the knowledge of an expert.

It is an important aspect of conservation and economy to develop the cattle industry (Szabo et al., 2000). The reasons for significant improvement in quantity and quality are the development of grasslands (about 1 million ha) (Dohy, 1999) and the utilisation of local conditions (Szabo, 1998). Since labour cost is the second highest following feeding cost (Bodo, 1998), development can only be achieved by improvement of work-place organisation and labour productivity (Horn, 2000).

Farms, including those in cattle keeping, work at different levels of development. Managers have to save not only on assets but also on labour, since this accounts for $15 \%$ of the total cost. This puts stress on examination of work-place organisation and rationalisation. That fact has led me to examine conditions of production and the level of management and work-place organisation on cattle keeping farms in Hajdú-Bihar county in Hungary. The goal of the study was to suggest an expert system model to help judge the level of work-place organisation. This is an alternative model and, according to the philosophy of expert systems, it is not a universal one.

\section{MATERIAL AND METHODS}

The field of decision support was dominated by the development of expert systems in the nineties. Expert systems are softwares based on logical reasoning which help handle problems that need human knowledge and experience to be solved. They model the way an expert reasons and makes suggestions that are based on the conclusions which may be formed for a decision-maker. An expert system is made up of two elements. One is the software (framework) and the other is the knowledge base (knowledge of an expert and a decision-maker). The software can be purchased. But the knowledge base is made up of the factors (called properties) that we use to describe the decision and we can express them by words. A knowledge base has four elements (Berki, 1995; Velencei, 1998):

1. Properties and their grades

2. Hierarchy of properties - decision-tree

3. ,if...then" rules between grades of properties

4. Knowledge (facts) about the topic

The framework is the DOCTUS knowledge based system. This knowledge base was developed by examining large-scale cattle keeping farms in the county, using five groups of factors determining work-place organisation, developed by Szendro and Szijjarto (1979). The groups of factors are the following: 
I. Work-place formation

II. Labour

III. Working process

IV. Way of incentive

V. Work-place climate

Questionnaires, personal monitoring and workday records completed by information from relevant literature implemented data collection. To model the knowledge collected this way, I used the method of rule based reasoning (RBR). The groups of factors and their elements represent the properties that are completed by grades. The framework allows us to create the decision tree based on the state of subordination of the properties. Subordination of the properties is described by rules. To enter the rules, we have to give a grade to each property (Dörfler and Velencei, 1999). The properties and their grades are presented in the results section of this paper.

\section{RESULTS AND DISCUSSION}

Level of organisation of an animal keeping organisation unit is determined by several factors. Experts are divided as to their actual role. But the different levels of organisation are also difficult to define, because there are no measurements for them. Nevertheless, connections like these can be formed into words, using an expert system.
Factors of organisation at a large-scale farm are influenced by operational conditions. These factors are considered as factors of decision making upon organisation. It is called „final conclusion” which we come to. In this case this is the level of work-place organisation that is a dependent factor like factors which influence it. But these influencing factors are also influenced by (dependent on) other factors. Therefore, there is a hierarchy of different factors called properties, as has been mentioned above, that can be displayed in the form of a decision tree (Figure 1).

Subordination of properties is described by rules. There are hundreds of combinations of the properties and their grades, and we highlighted some of them as an introduction to them (Table 1).

Combinations of grades of the properties shown in Figure 1 determine the level of work-place organisation. The grades given to each property can be ranked from the poorest to the highest (best). For work-place organisation, the poorest grade is the „under-organised" and highest is the ,wellorganised" one. The grades representing different levels of work-place organisation can be connected with alternatives of actions to improve state of organisation. The properties and grades in this study are optional, because their role and importance can be considered differently by experts with many years of experience.

Figure 1: Properties affecting work-place organisation and their grades

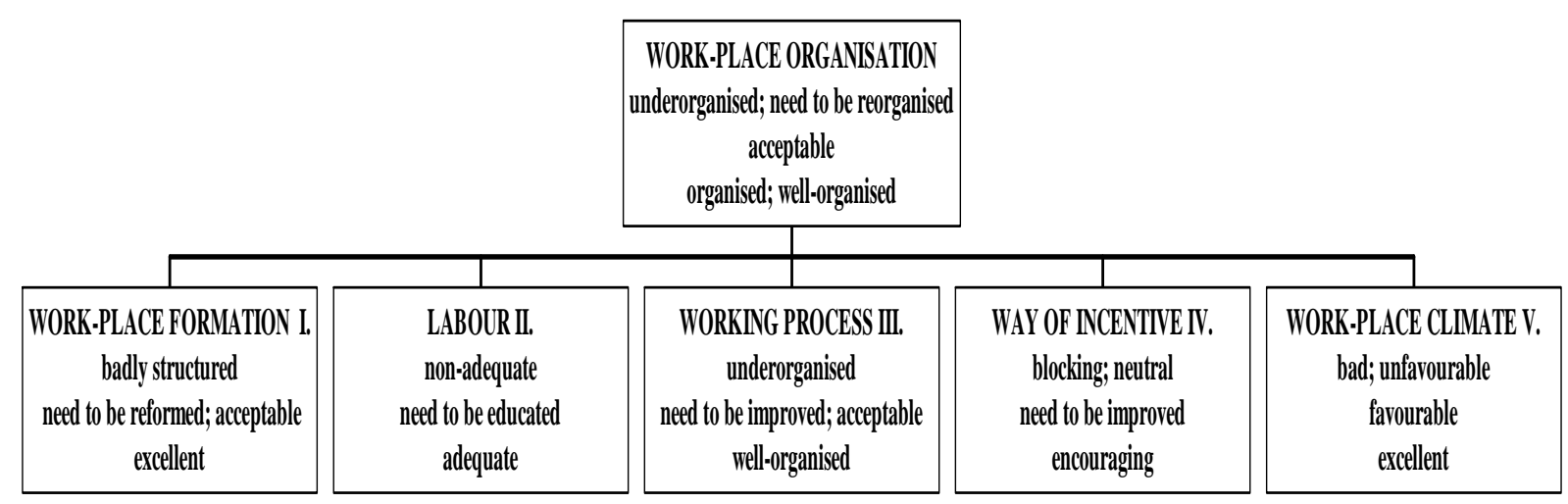

Table 1: Relationship between grades of properties of work-place organisation described by „if...then” decision rules (sample)

\begin{tabular}{|c|c|c|c|c|c|}
\hline $\begin{array}{c}\text { IF... } \\
\text { The work-place } \\
\text { formation (1) }\end{array}$ & $\begin{array}{c}\text { AND IF... } \\
\text { The labour } \\
\text { (2) }\end{array}$ & $\begin{array}{c}\text { AND IF... } \\
\text { The working } \\
\text { process (3) }\end{array}$ & $\begin{array}{c}\text { AND IF... } \\
\text { Way of incentive } \\
(4) \\
\end{array}$ & $\begin{array}{c}\text { AND IF... } \\
\text { Work-place climate } \\
\text { (5) }\end{array}$ & $\begin{array}{c}\text { THEN } \\
\text { The work-place } \\
\text { organisation (6) }\end{array}$ \\
\hline$*$ & $*$ & Underorganised & Neutral & $\mathrm{Bad}$ & Underorganised \\
\hline Badly-structured & Non-adequate & Acceptable & Need to be improved & $\mathrm{Bad}$ & Underorganised \\
\hline Badly-structured & Non-adequate & Acceptable & $*$ & Excellent & Underorganised \\
\hline Badly-structured & Adequate & Well-organised & Neutral & $\mathrm{Bad}$ & Underorganised \\
\hline Badly-structured & Adequate & Well-organised & Neutral & Excellent & Need to be reorganised \\
\hline Excellent & Non-adequate & Well-organised & Encouraging & Unfavourable & Need to be reorganised \\
\hline Acceptable & Need to be educated & Acceptable & Need to be improved & Favourable & Acceptable \\
\hline Excellent & Need to be educated & Well-organised & Encouraging & Excellent & Organised \\
\hline Excellent & Adequate & Well-organised & Encouraging & Excellent & Well-organised \\
\hline
\end{tabular}

Remark: * = in the case of any property grades 
The number of combinations of the properties and their grades is great but not all of them exist in real life. Nevertheless, we have to take all of them into consideration to make all the connections then we can leave some out or reduce based on their logical relationships. According to ,if...then” rules, we read Table 1 as follows: If the work-place is badly structured, and if labour is non-adequate, and if the working process is acceptable, and if the way of incentive needs to be improved, and if the work-place climate is bad, then the work-place organisation is underorganised. In this case, the manager has to take actions which are developed as an alternative to the action worked out for this level of organisation.

I used the developed model to examine workplace organisation on seven cattle keeping farms. Results are shown in Table 2.

Table 2: Results of examination of factors (properties) influencing work-place organisation on cattle keeping farms

\begin{tabular}{|c|c|c|c|c|c|c|c|}
\hline Factors & CKF1 & CKF2 & CKF3 & CKF4 & CKF5 & CKF6 & CKF7 \\
\hline $\begin{array}{c}\text { Work-place } \\
\text { formation }\end{array}$ & $\begin{array}{l}\text { Need to be } \\
\text { reformed }\end{array}$ & acceptable & acceptable & excellent & acceptable & excellent & acceptable \\
\hline $\begin{array}{c}\text { Work-place } \\
\text { climate }\end{array}$ & bad & unfavourable & unfavourable & unfavourable & bad & bad & unfavourable \\
\hline $\begin{array}{l}\text { Working } \\
\text { process }\end{array}$ & $\begin{array}{c}\text { Under- } \\
\text { organised }\end{array}$ & $\begin{array}{c}\text { Need to be } \\
\text { improved }\end{array}$ & $\begin{array}{c}\text { Need to be } \\
\text { improved }\end{array}$ & $\begin{array}{c}\text { Need to be } \\
\text { improved }\end{array}$ & $\begin{array}{l}\text { Need to be } \\
\text { improved }\end{array}$ & $\begin{array}{c}\text { Need to be } \\
\text { improved }\end{array}$ & $\begin{array}{c}\text { Need to be } \\
\text { improved }\end{array}$ \\
\hline Labour & Non-adequate & $\begin{array}{l}\text { Need to be } \\
\text { educated }\end{array}$ & Non-adequate & Non-adequate & $\begin{array}{l}\text { Need to be } \\
\text { educated }\end{array}$ & Non-adequate & Non-adequate \\
\hline $\begin{array}{c}\text { Way of } \\
\text { incentive }\end{array}$ & encouraging & encouraging & encouraging & encouraging & encouraging & encouraging & encouraging \\
\hline $\begin{array}{c}\text { Work-place } \\
\text { organisation }\end{array}$ & $\begin{array}{c}\text { under- } \\
\text { organised }\end{array}$ & acceptable & acceptable & acceptable & $\begin{array}{c}\text { need to be } \\
\text { reorganised }\end{array}$ & $\begin{array}{c}\text { need to be } \\
\text { reorganised }\end{array}$ & acceptable \\
\hline
\end{tabular}

Remark: CKF1 means cattle keeping farm 1 etc.

I found that the work-place organisation is underorganised on cattle keeping farm 1 , needs to be reorganised on cattle keeping farms 5 and 6, and acceptable on the rest of the farms involved. I stated that the model could be used to ,measure" the level of work-place organisation. Based on the results in Table 2, work-place organisation has to be improved on farms involved in the examination. I suggest that each manager should evaluate the influencing factors that led to these results. They should go into details, following the rest of the factors on which the five influencing factors are dependent. These factors are not introduced in the papers but the model would not work without them. Managers should work out some alternatives of actions to improve these factors and select the one they find satisfactory.

\section{CONCLUSIONS AND RECOMMENDATIONS}

- Expert systems can be used to examine organisations because of their principles and structures.

- I recommend the use of an expert system to restructure knowledge pools and organisational auditing systems already used to rationalise farm businesses.

- Work-place organisation is a non-measurable attribute of a farm, but an expert system can assist a manager in making decisions which will continuously improve his farm business.

- Expressing non-measurable characteristics make the evaluation of an organisation easier and help reveal which factors should be improved, using a particular action worked out for it.

\section{REFERENCES}

Badiru, A. B. (1988): Successful Initiation of Expert Systems Projects. IEEE Transactions on Engineering Management, 35. 3. August

Baracskai, Z. (1997): Professional decisions. Nyíregyháza, 71.

Benders, J.-Manders, F. (1993): Expert Systems and Organisational Decisions Making. Information and Management, 25. 207-213.

Berki, S. (1995): „But do not be sad my valiant fellow...” UEB Managers' Training Institution, Budapest, 48-51.

Bodo, I. (1998): Profitability of suckler beef cattle. Suckler beef cattle breeding, Mezőgazda Kiadó, Budapest, 348-356.

Cooke, T. (1991): Expert Systems: Panacea or just a Niche Tool? OR/MS Today, June 6-8.

Dohy, J. (1999): Suggestions to development of animal husbandry.
Gazdálkodás, XLIII. 6. 19-24.

Dologite, D. G.-Mockler, R. J. (1989): Developing Effective Knowledge Based Systems: Overcoming Organisational and Individual Barriers. Information Resource Journal, Winter 2739.

Dörfler, V.-Velencei, J. (1999): Knowledge structuring. Economy Enterprise Leadership, 4. 64-73.

Horn, P. (2000): Some issues of development of animal breeding in Hungary. Animal Breeding and Nutrition, 49. 1. 3-12.

Kunnathur, A. S.-Ahmed, M. U.-Charles, R. J. S. (1996): Expert systems adoption An analytical study of managerial issues and concerns. Information and Management, 30. 15-25.

Szabo, F. (1998): Suckler beef cattle breeding. Mezőgazda Kiadó, Budapest 
Szabo, F.-Lengyel, Z.-Wagenhoffer, Zs.-Dohy, J. (2000): Parameters of population genetics in beef cattle breeding. Animal Breeding and Nutrition, 49. 3. 193-205.

Szendro, L.-Szijjarto, A. (1979): Method of analysis of workplace organisation. Agricultural Research Institution, Budapest, 83.

Szenteleki, K.-Horvath, T.-Majzik, Zs. (1998): Conceptual problems and problems in practice with expert systems during development. University of Agriculture Gödöllő, Gazdaság- és Társadalomtudományi Kar, Tudományos Közlemények 2. „Vállalati környezet és alkalmazkodás az élelmiszeriparban” II. kötet, 71-74.

Velencei, J. (1998): Expert's knowledge. Vezetéstudomány, XXIX. 10. 20

Wiig, K. (1990): Expert systems. A manager's guide. International Labour Office, Geneva, 12. 